\title{
3-D Seismic Structural Interpretation of High Field Offshore Western Niger Delta
}

\section{${ }^{* 1}$ ADEBAYO, SS; ${ }^{2}$ AGBALAGBA, EO; ${ }^{3} \mathrm{KORODE}$, AI; ${ }^{4} \mathrm{FAGBEMIGUN,} \mathrm{TS;}$ ${ }^{5}$ OYANAMEH, OE; ${ }^{6}$ OSISANYA, OW}

\author{
${ }^{I}$ Department of Applied Geophysics, Federal University of Technology Akure, Ondo State, Nigeria \\ ${ }^{2}$ Department of Physics, Federal University of Petroleum Resources, Effurun Delta State, Nigeria \\ ${ }^{3}$ Department of Petroleum Engineering and Geoscience, Petroleum Training Institute, Effurun, Nigeria \\ ${ }^{4}$ Department of Geophysics, Federal University, Oye-Ekiti, Nigeria. \\ ${ }^{5}$ Anchor University, Lagos, Nigeria \\ ${ }^{* 6}$ Department of Physics, University of Benin, Benin City, Edo State, Nigeria \\ *Corresponding Author Email: wasiu.osisanya@uniben.edu
}

\begin{abstract}
Seismic Structural interpretation of subsurface system is a vital tool in mapping source rocks and good trapping system which enhances good understanding of the subsurface system for productive drilling operation. This study is geared towards mapping the structural traps available within the hydrocarbon bearing zones of the "High field" with the use of well $\log$ and $3 \mathrm{D}$ seismic data. Seven horizons $\left(\mathrm{H}_{1}, \mathrm{H}_{2}, \mathrm{H}_{3}, \mathrm{H}_{4}, \mathrm{H}_{5}, \mathrm{H}_{6}\right.$ and $\left.\mathrm{H}_{7}\right)$ were identified on well logs using gamma ray log and resistivity logs. Nine (9) faults were mapped on seismic sections across the field, two (2) of which are major growth faults $\left(\mathrm{F}_{1}\right.$ and $\left.\mathrm{F}_{2}\right)$, two (2) synthetic faults $\left(\mathrm{F}_{3}\right.$ and $\left.\mathrm{F}_{7}\right)$ and five (5) antithetic faults $\left(\mathrm{F}_{4}, \mathrm{~F}_{5}, \mathrm{~F}_{6}, \mathrm{~F}_{8}\right.$ and $\left.\mathrm{F}_{9}\right)$. Rollover anticlines which are structural closure and displayed on the depth structural maps suggest probable hydrocarbon accumulation at the down throw side of the fault $F_{1}$. Structural interpretation of high field has revealed a highly fault assisted reservoir which depicts the tectonic setting of Niger Delta basin
\end{abstract}

\section{DOI: https://dx.doi.org/10.4314/jasem.v25i8.4}

Copyright: Copyright (C) 2021 Adebayo et al. This is an open access article distributed under the Creative Commons Attribution License (CCL), which permits unrestricted use, distribution, and reproduction in any medium, provided the original work is properly cited.

Dates: Received: 10 May 2021; Revised: 28 June 2021; Accepted: 01 July 2021

Keywords: Seismic, Structural, Faults, Niger Delta

Niger Delta has a distinctive structural and stratigraphic zonation. Regional and counter-regional growth faults, developed in an outer-shelf and upperslope setting, are linked via a translational zone containing shale diapirs to a contractional zone defined by a fold-thrust belt developed in a toe-ofslope setting (Hooper et al., 2002). Subsurface configurations must be understood in detail to effectively delineate the structures that are favourable for hydrocarbon accumulation (Coffen, 1984). This is because hydrocarbons are found in geologic traps, that is, any combination of rock structure that will keep oil and gas from escaping either vertically or laterally. However, these traps can either be structural or stratigraphic. Majority of the traps in the Niger Delta are structural (Doust and Omatsola, 1989). Structural interpretation is an important aspect of the development programme of a field. It has diverse application in many areas of 3- D seismic interpretation including helping to effectively analyse controlling influences on reservoir geometry, position and hydrocarbon migration pathways. Sometimes the estimate of reserves may even be dependent on structural interpretation when fluid contacts located on depth structure maps are needed as inputs in volumetric analysis, (Jon and Richard, 2004). ). Therefore, this study is channelled towards mapping the structural traps available within the hydrocarbon bearing zones (reservoirs) of the study area using 3D seismic data and well log which will lead to a better understanding of the subsurface geology of the study area, which enhance location of productive wells.

Location and geology of The Study Area: The study area, "High field"' is located in the Niger Delta, which is situated in the Gulf of Guinea in the Niger Delta Province (Klett et al, 1997). The petroliferous Niger Delta is one of the highest producing basins with more promising reserves yet to be discovered as exploration proceeds to the deeper water (Rotimi, 2010). "High field" is located within the western margin of offshore Niger Delta (Figure 1a) and belongs to Chevron Texaco Nigeria Limited. Figure $1 b$ is the base map of "High field"'. The Niger Delta clastic wedge formed along a failed arm of a triple junction system (aulacogen) that originally developed during breakup of the South American and African plates in the late Jurassic, (Burke, 1972; Whiteman, 1982). The two arms that followed the southwestern and southeastern coast of Nigeria and Cameroon developed into the 
passive continental margin of West Africa, whereas the third failed arm formed the Benue Trough. Other depocenters along the African Atlantic coast also contributed to deltaic build-ups. Synrift sediments accumulated during the Cretaceous to Tertiary, with the oldest dated sediments of Albian age. Thickest successions of synrift marine and marginal marine clastics and carbonates were deposited in a series of transgressive and regressive phases, (Doust and Omatsola, 1989). The Synrift phase ended with basin inversion in the Santonian (Late Cretaceous).

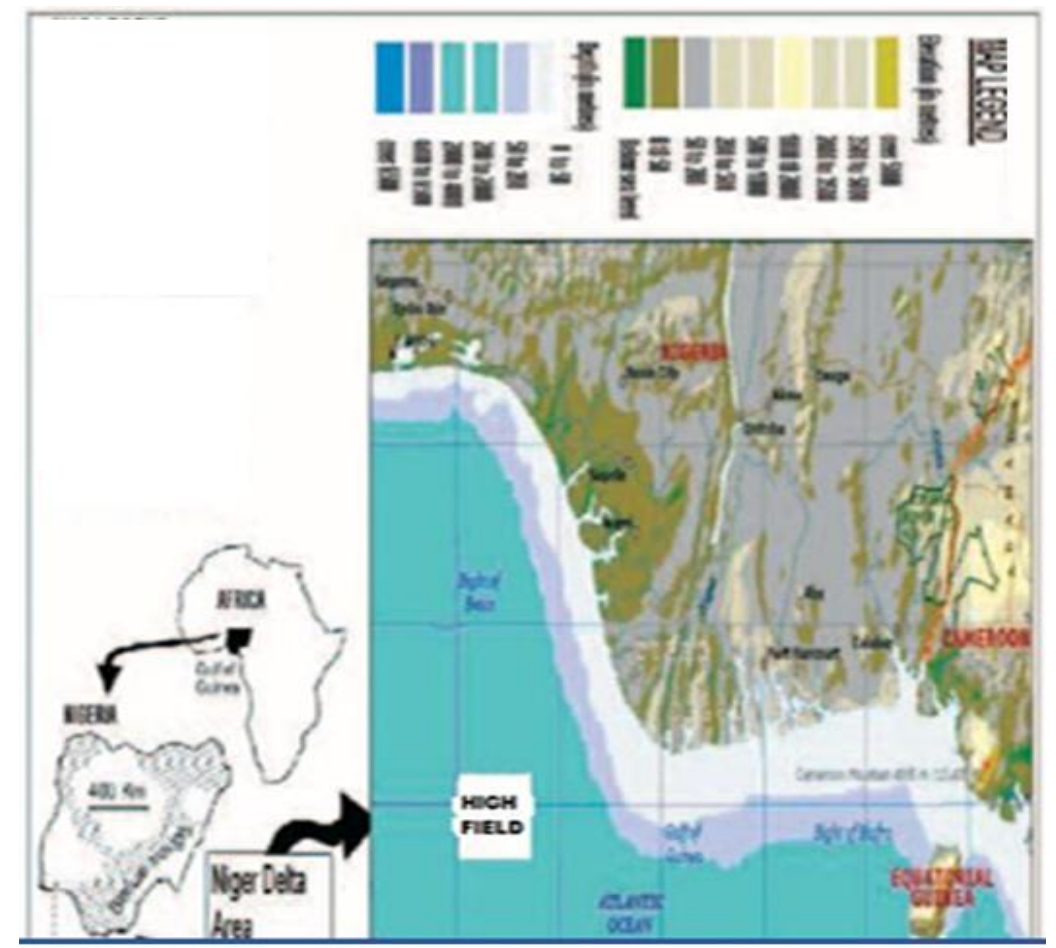

Fig 1a: Location map of the study area (After Owoyemi, 2004 and Microsoft Encarta,

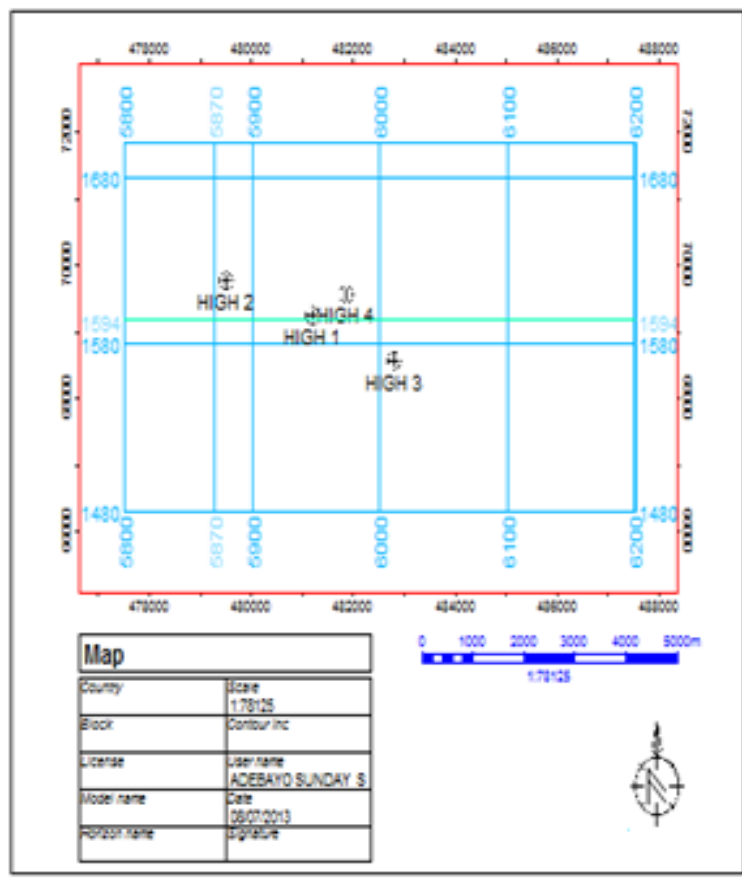

Fig 1b: Seismic Survey Base Map of "High Field"' showing the location of the four wells and seismic section.
Galloway et al., (1982), observed that Synsedimentary normal faults, or growth faults, associated with deltas are involved in the formation of major traps for oil and gas reservoirs and they may isolate compartments in subsurface hydrocarbon reservoirs or aquifers. Ako et al., (2004), observed from gravity data, that the most favorable areas for hydrocarbon accumulation are the zones of structural lows, which are deeper than $3900 \mathrm{ft}(1300 \mathrm{~m})$ and represent the sub-basin in the Niger Delta and adjacent basins such as Anambra basin and the Benue Trough. Avbovbo (1978), identified growth faults antithetic and synthetic faults and roll-over anticlines as the major syn-sedimentary structures associated with the Niger Delta. Adeoye and Enikanselu (2009), generated structural maps that revealed fault assisted closures at the centre "Extreme" Field, South-western Niger Delta using Seismic and Borehole data, which correspond to the crest of rollover anticlines and possibly served as the trapping medium. Growth fault triggered by contemporaneous deformation of deltaic sediment are the common structures in the Niger delta (Merki, 1972; Evamy et al., 1978). They are generated by rapid sedimentation 
and gravitational instability during the accumulation of the Agbada deposits and continental Benin sands over the mobile under compacted Akata prodelta shale. Lateral flowage and extrusion of the Akata prodelta shale during growth faulting also account for the diapiric structure on the continental slope of the Niger delta in front of the advancing depocentre of paralic sediment. Amigun (2007) determined the principal types of structures that serves as traps in ' $\mathrm{X}$ 'field eastern Niger Delta using a 2D seismic structural interpretation. The structural style, both on regional and on the field scale, can be explained on the basis of influence of the ratio of sedimentation to subsidence rates. The different types of structures are namely, simple non-faulted anticline rollover structures, faulted rollover anticline with multiple growth faults, or anticline faults and complicated collapse crest structures, (Evamy et al., 1978). Others are subparallel growth fault (k-block structures) and structural
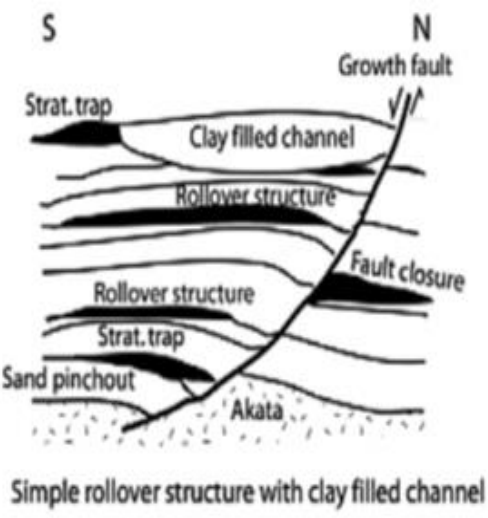

$S$

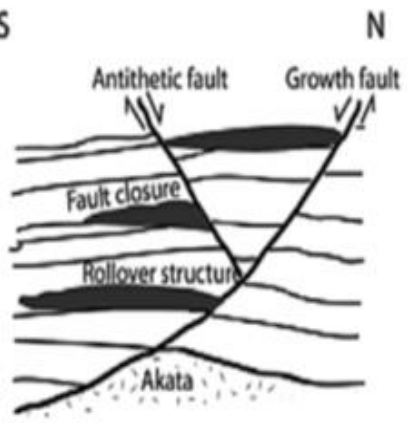

Structure with antithetic fault closures along the back of major growth faults (Figure 2). Normal faults triggered by the movement of deepseated, over pressured, ductile, marine shale have deformed much of the Niger Delta clastic wedge, (Doust and Omatsola, 1989). Many of these faults formed during delta progradation and were syndepositional, affecting sediment dispersal. Fault growth was also accompanied by slope instability along the continental margin. Faults flatten with depth onto a master detachment plane near the top of the over pressured marine shales at the base of the Niger Delta succession. Structural complexity in local areas reflects the density and style of faulting. Simple structures, such as flank and crestal folds, occur along individual faults. Hanging-wall rollover anticlines developed because of listric-fault geometry and differential loading of deltaic sediments above ductile shales (Figure 2).

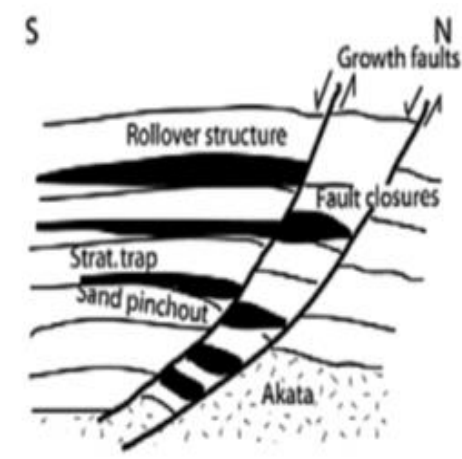

Structure with multiple growth faults

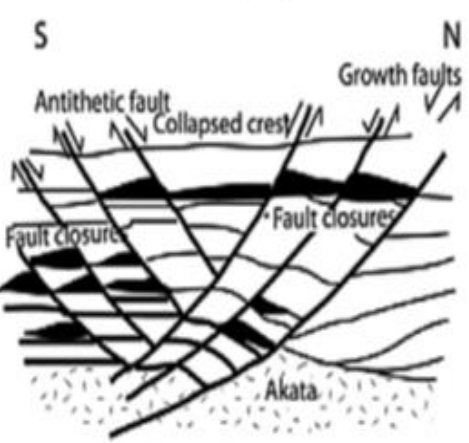

Collapsed crest structure

Fig 2. Niger Delta oil field structures and associated traps (After Doust and Omatsola, 1989 and Stacher, 1995).

\section{MATERIALS AND METHODS}

The set of data used for this study are 3-D seismic data (SEG Y format), suite of well logs (self-potential, gamma ray and resistivity logs, checkshot survey data with the use of petrel work tool (2010) software. Well logs and 3-D seismic data, in LAS and SEG-Y formats respectively, were loaded into the workstation for interpretation (Figure 3). Lithostratigraphic well correlation of sand bodies within the Agbada
Formation was carried out along the West-East direction to determine the lithologies penetrated by the studied wells using resistivity log and gamma ray log. The cut-off point for the gamma ray logs was set at 65 API. From the gamma ray and resistivity logs, sand bodies containing hydrocarbon were identified. Horizons and faults were mapped on the 3-D seismic volume to generate time and depth structure maps in order to determine area of possible oil well locations as faults may serve as pathway for the migration of 
hydrocarbon. This was followed by generating a fault model in order to determine the trends of the faults in the study area. Throws of the major faults were determined and were used to determine the sealing potential of the faults.

Tying of well data to seismic data was carried out using a synthetic seismogram. The synthetic seismogram was made from density and sonic log data from HIGH 4 well. During the process, wavelets frequency are optimized for accurate match between generated synthetics from the wells and seismic traces.

\section{RESULTS AND DISCUSSION}

Prior to any meaningful interpretation, there is need to establish the hydrocarbon bearing zones i.e. the reservoirs. This was done both on well data and seismic section. The hydrocarbon bearing zones is the sandstones of the Agbada Formation, on the seismic section it consists of parallel and high amplitude reflections having reflection interval between $1.35 \mathrm{~s}$ to $2.8 \mathrm{~s}$ two-way travel time. The Agbada Formation is further divided into the upper and lower formations based on the sand to shale ratio of the gamma ray log of HIGH 4 well. The upper Agbada Formation has a higher sand to shale ratio than the lower Agbada Formation.

Lithostratigraphic Well Log Correlation: The lithostratigraphic well log correlation was done using gamma ray and resistivity logs (Figure $4 \mathrm{a}-\mathrm{b}$ ). Seven sand bodies were identified, which include Sand A, Sand B, Sand C, Sand D, Sand E, Sand G and Sand F. The identified sand bodies are not clean but still have intercalations of shales in them. Sand A has the highest thickness ranging from $4600 \mathrm{ft}(1402.1 \mathrm{~m})$ to $7400 \mathrm{ft}$ $(2255.5 \mathrm{~m})$, Sand B has a depth which ranges from $7500 \mathrm{ft}$ (2286.0 m) to $7900 \mathrm{ft}$ (2407.9 m). Others, Sand C, Sand D, sand E, Sand F and Sand G ranges from $8060 \mathrm{ft}(2456.7 \mathrm{~m})$ to $8900 \mathrm{ft}(2712.7 \mathrm{~m}), 9100 \mathrm{ft}$ $(2773.7 \mathrm{~m})$ to $9400 \mathrm{ft}(2865.1 \mathrm{~m}), 9500 \mathrm{ft}(2895.6 \mathrm{~m})$ to $10300 \mathrm{ft}(3139.4 \mathrm{~m}), 10500 \mathrm{ft}(3200.4 \mathrm{~m})$ to 10850 ft $(3307.08 \mathrm{~m})$ and $11100 \mathrm{ft} .(3383.28 \mathrm{~m})$ to $11250 \mathrm{ft}$ (3429 m) respectively. Sands E, F and G are probable hydrocarbon reservoirs due to their high resistivities as indicated by the resistivity log since hydrocarbons have high resistivities if unbiodegraded. Within the logged intervals, the lithology is dominated by alternating sand and shale, occurring approximately in a $65: 35$ ratio.

Faults and Horizons Interpretation: Faults and Horizons interpretation were carried out in order to produce the time and depth structure maps. Seven horizons were picked which marked the top of sand bodies within the Agbada Formation. The seven horizons $\left(\mathrm{H}_{1}, \mathrm{H}_{2}, \mathrm{H}_{3}, \mathrm{H}_{4}, \mathrm{H}_{5}, \mathrm{H}_{6}\right.$, and $\left.\mathrm{H}_{7}\right)$ were identified on well logs using gamma ray $\log$ and resistivity log and on seismic section through synthetic seismogram correlation with well logs. Nine (9) faults were mapped on the seismic sections across the field (Figure 5).

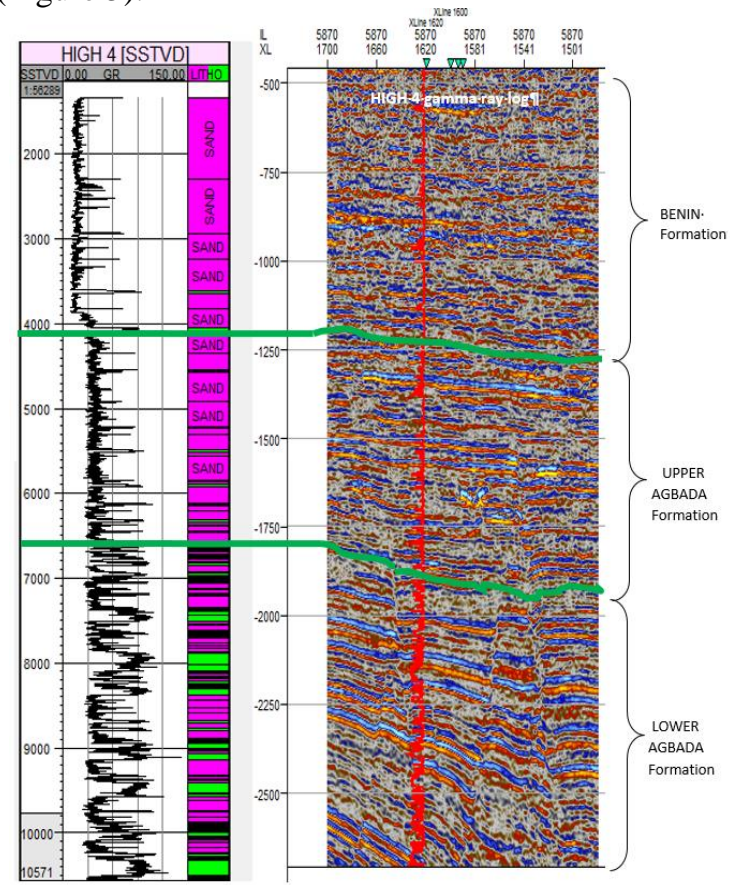

Fig 3: Gamma ray log and seismic section inline 5880 showing the Upper Agbada Formation and the Lower Agbada Formation which was characterised based on the reflection characteristics of the seismic inline and the sand to shale ratio from the gamma ray log.

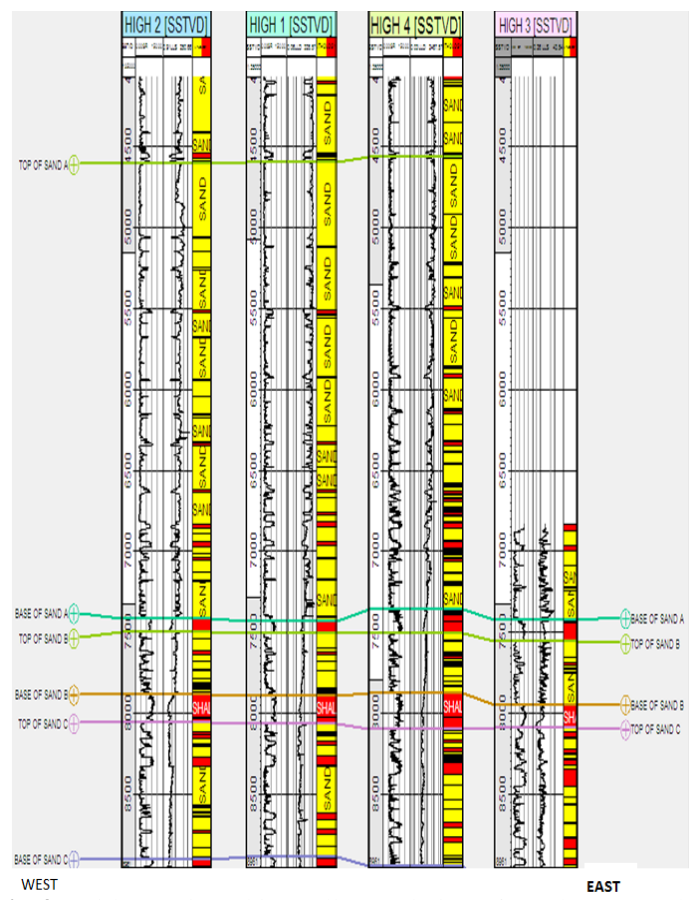

Fig 4a: Lithostratigraphic Well Correlation of Sand A to Sand B along West-East direction. 


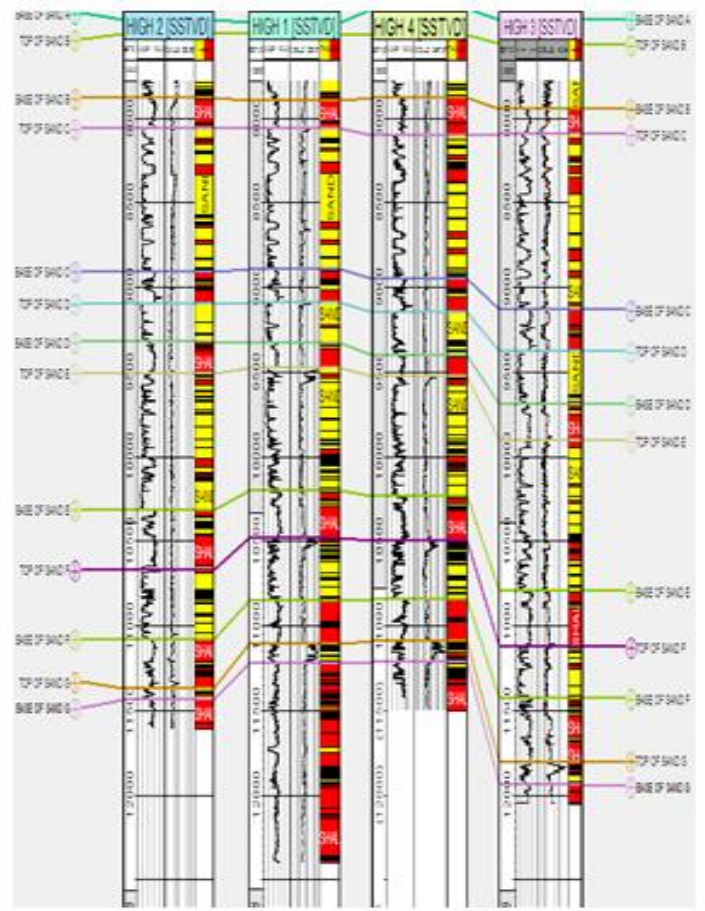

PROXIMAL

DISTAL

Fig 4b: Lithostratigraphic Well Correlation of Sand C to Sand G along West-East direction

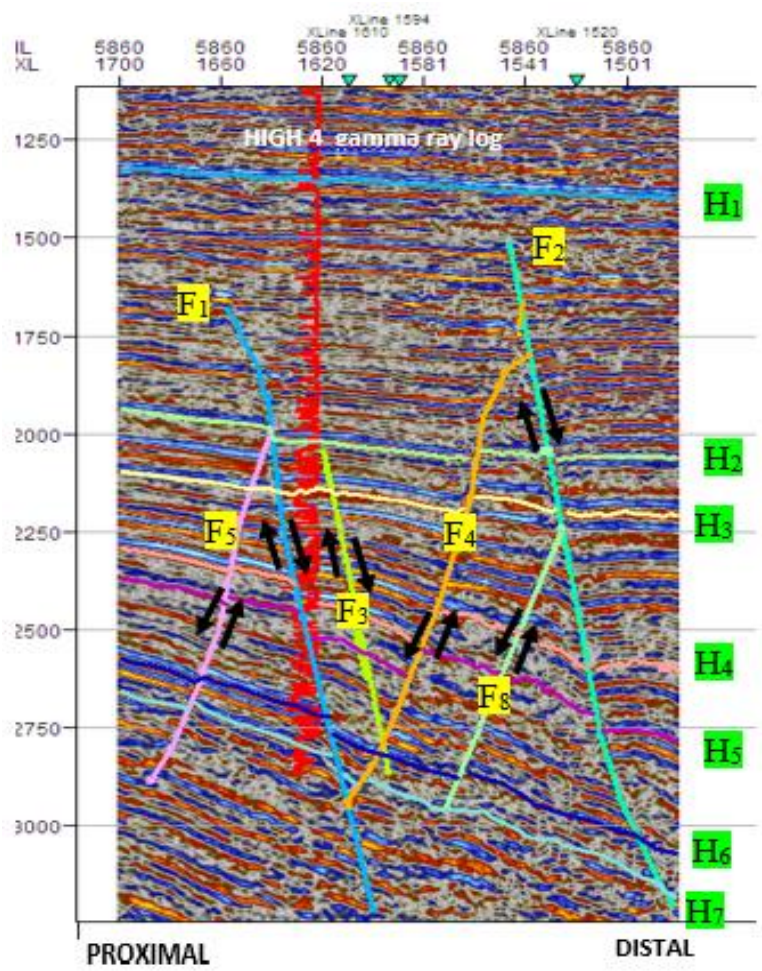

Fig 5: Interpreted Seismic section showing mapped horizons $\mathrm{H}_{1}$ to $\mathrm{H}_{7}$, faults $\mathrm{F}_{1}$ to $\mathrm{F}_{8}$ and gamma ray $\log$ of $\mathrm{HIGH} 4$ well on inline 5860 .

Faults Interpretation: Nine faults labelled $\mathrm{F}_{1}, \mathrm{~F}_{2}, \mathrm{~F}_{3}$, $\mathrm{F}_{4}, \mathrm{~F}_{5}, \mathrm{~F}_{6}, \mathrm{~F}_{7}, \mathrm{~F}_{8}$ and $\mathrm{F}_{9}$ were mapped across the seismic sections. Faults $F_{1}$ and $F_{2}$ are the major faults, faults $F_{4}, F_{5}, F_{6}, F_{8}$ and $F_{9}$ are antithetic faults while faults $F_{3}$ and $F_{7}$ are synthetic to the major faults. Fault $F_{1}$ is located in the proximal part of the field while $F_{2}$ is located in the distal part of the field (Figure 6). Faults were enhanced for better resolution on the 3-D seismic section using the Variance attribute. Variance is used to enhance an edge volume from an input seismic volume (Petrel Workflow Tool, 2010). Variance only highlights vertical variation in acoustic impedance. It compares traces next to each other at each sample position. If there is a difference it's probably due to a fault or channels (Vikesh 2013). Figure 7 shows the discontinuities (faults and probably channels), with the major faults $F_{1}$ and $F_{2}$ in yellow circles.

The fault model in Figure 4.6 shows faults $F_{1}, F_{2}, F_{3} F_{4}$, $\mathrm{F}_{5}, \mathrm{~F}_{7}$ and $\mathrm{F}_{8}$, [ $\mathrm{F}_{9}$ (hidden) occur at the rear side beside $F_{7}$. The major faults $F_{1}$ and $F_{2}$ are trending in the West-East direction and dipping in the NW-SE direction which further support the work by Hosper, (1971). The faults may serve as significant tools in trapping of hydrocarbon sands especially the major growth fault $F_{1}$ that is laterally extensive in the study area.

Horizons Interpretation: The mapped horizons $\left(\mathrm{H}_{1}\right.$, $\mathrm{H}_{2}, \mathrm{H}_{3}, \mathrm{H}_{4}, \mathrm{H}_{5}, \mathrm{H}_{6}$, and $\mathrm{H}_{7}$ ) represent the top of sand bodies as shown in Figure $5 . \mathrm{H}_{7}$ is the basal horizon serving as the oldest of the mapped horizons in this study, it marks the top of sand $G$ having a two way travel time between $2750 \mathrm{~ms}$ to $3150 \mathrm{~ms}$. It is continuous in most part of the field and has a welldefined character. Tracking of the event over the field is quite reliable except in faulted zones where it proves challenging. $\mathrm{H}_{6}$ represents reflections emanating from interphase between $2350 \mathrm{~ms}$ to $3100 \mathrm{~ms}$ and mark the top of sand $\mathrm{F}$, like $\mathrm{H}_{7}$, it is quite reliable and continuous across the entire field. $\mathrm{H}_{5}$ represents reflections corresponding to the two way travel time ranging from $2340 \mathrm{~ms}$ to $2620 \mathrm{~ms}$, it marks the top of sand $\mathrm{E}$. $\mathrm{H}_{4}$ is the middle horizon representing reflections from 2200 $\mathrm{ms}$ to $2540 \mathrm{~ms}$ and marks the top of sand D. It is also continuous in most part of the field and has a welldefined character. $\mathrm{H}_{3}$ represents reflections corresponding to the two way travel time ranging from $2080 \mathrm{~ms}$ to $2300 \mathrm{~ms}$, it marks the top of sand C. Tracking was relatively easy except at faulted regions on the seismic sections. $\mathrm{H}_{2}$ has reflections corresponding to $1960 \mathrm{~ms}$ to $2160 \mathrm{~ms}$ two-way travel time marking the top of sand $\mathrm{B}$. $\mathrm{H}_{1}$ is the topmost horizon serving as the youngest of the mapped horizons in this study. It marks the top of sand A across the field and represent reflections ranging from 1280 $\mathrm{ms}$ to $1420 \mathrm{~ms}$. 


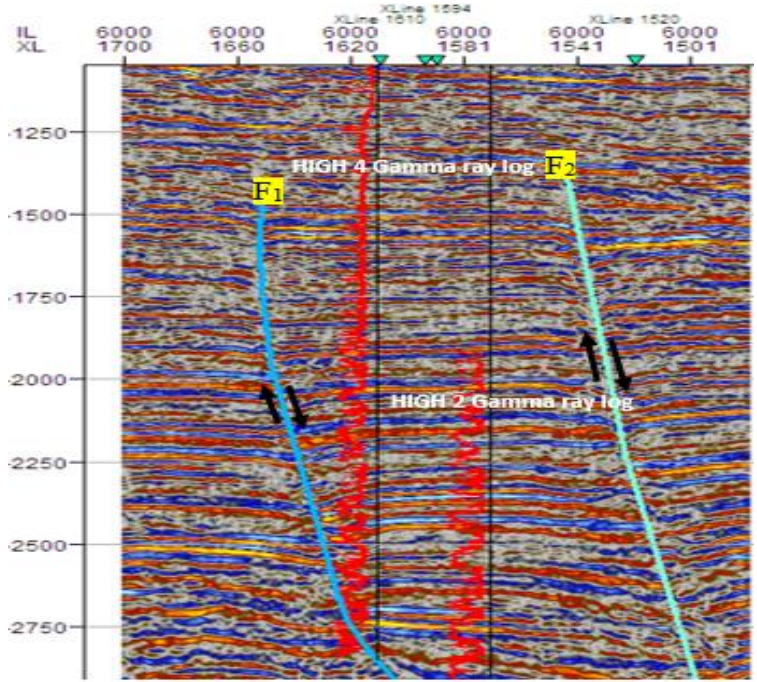

Fig 6: Interpreted Seismic section showing major faults $F_{1}$ and $F_{2}$, and gamma ray logs of HIGH 4 and HIGH 2 wells on inline 6000 .

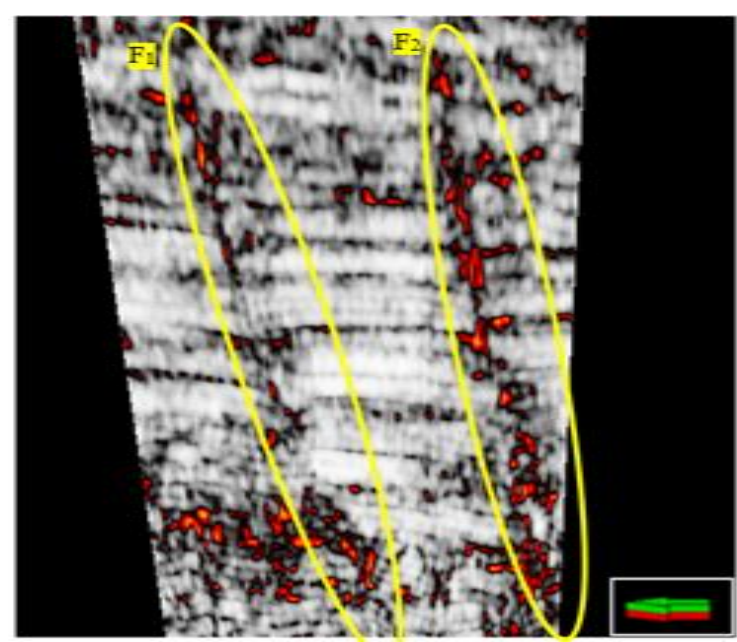

Fig 7: Interpreted seismic section of Variance attribute on inline 6000 showing major faults $F_{1}$ and $F_{2}$ in yellow circles.

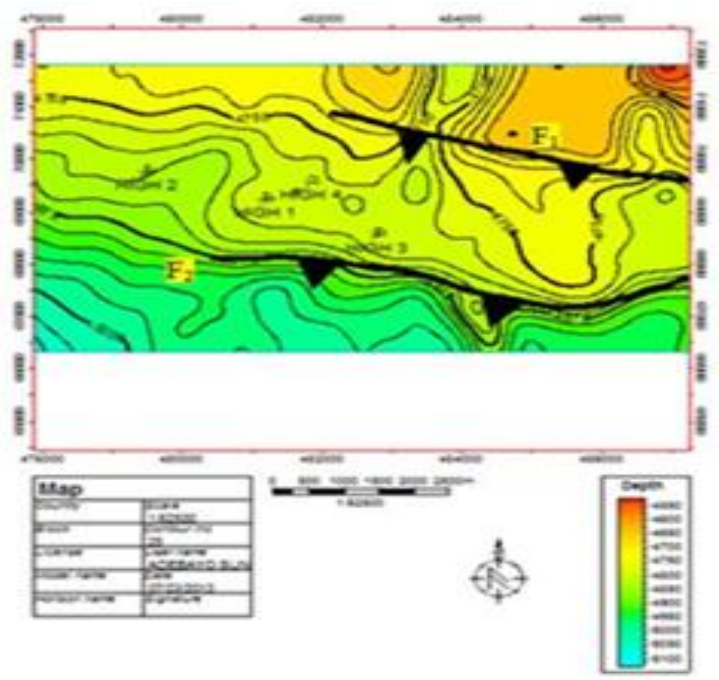

Fig 8: Depth Map for $\mathrm{H}_{1}$ (Contour Interval $25 \mathrm{ft}$ )

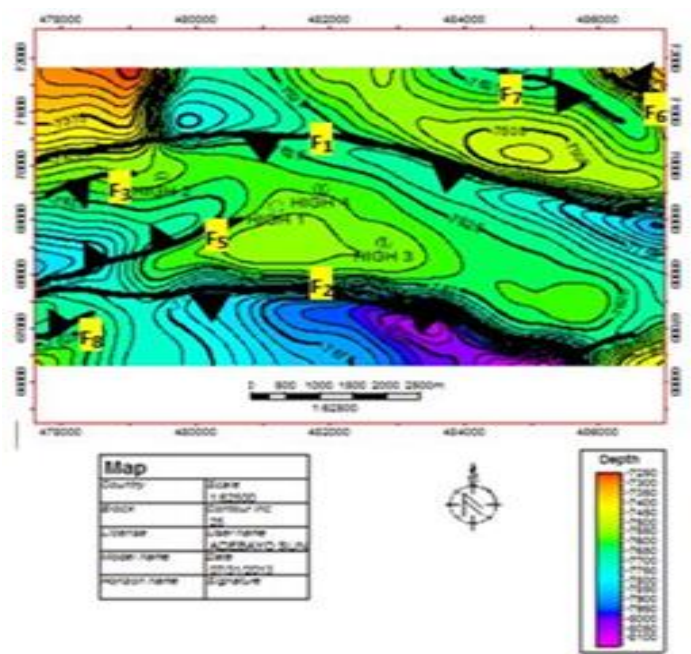

Fig 9: Depth Map for $\mathrm{H}_{2}$ (Contour Interval $25 \mathrm{ft}$ )

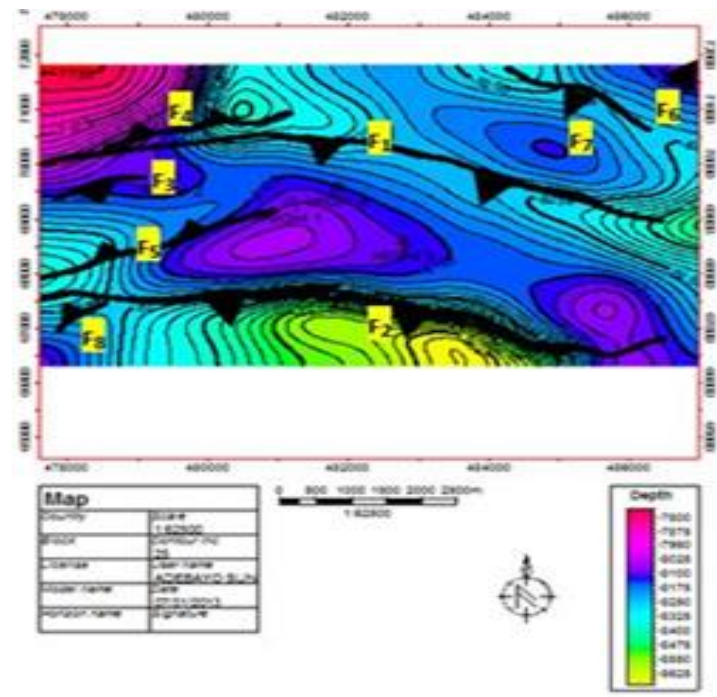

Fig 10: Depth Map for $\mathrm{H}_{3}$ (Contour Interval $25 \mathrm{ft}$ ).

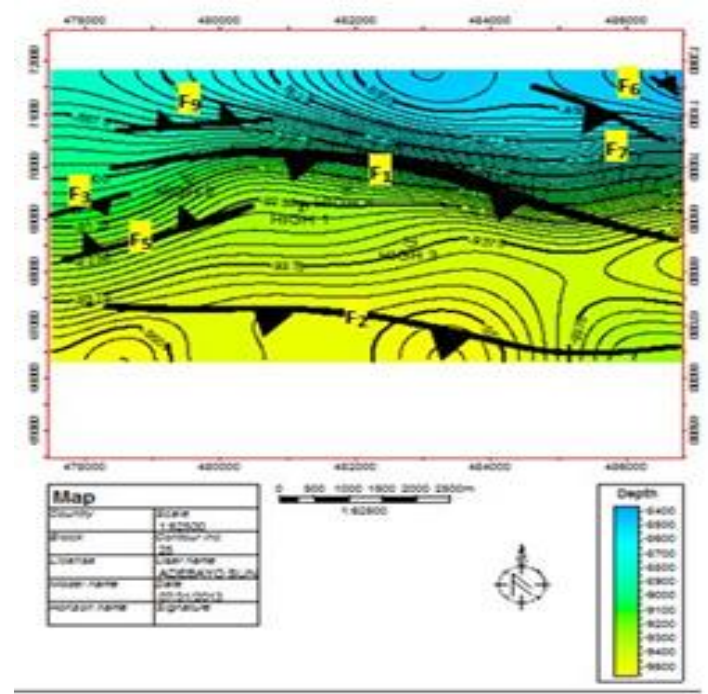

Fig 11: Depth Map for $\mathrm{H}_{4}$ (Contour Interval $25 \mathrm{ft}$ ).

ADEBAYO, SS; AGBALAGBA, EO; KORODE, AI; FAGBEMIGUN, TS; OYANAMEH, OE; OSISANYA, OW 


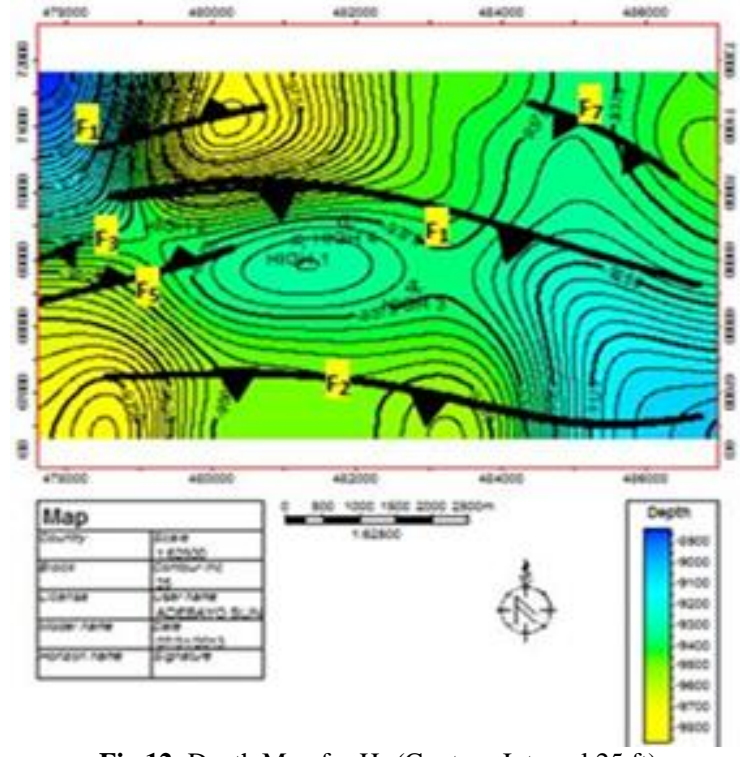

Fig 12: Depth Map for $\mathrm{H}_{5}$ (Contour Interval $25 \mathrm{ft}$ )

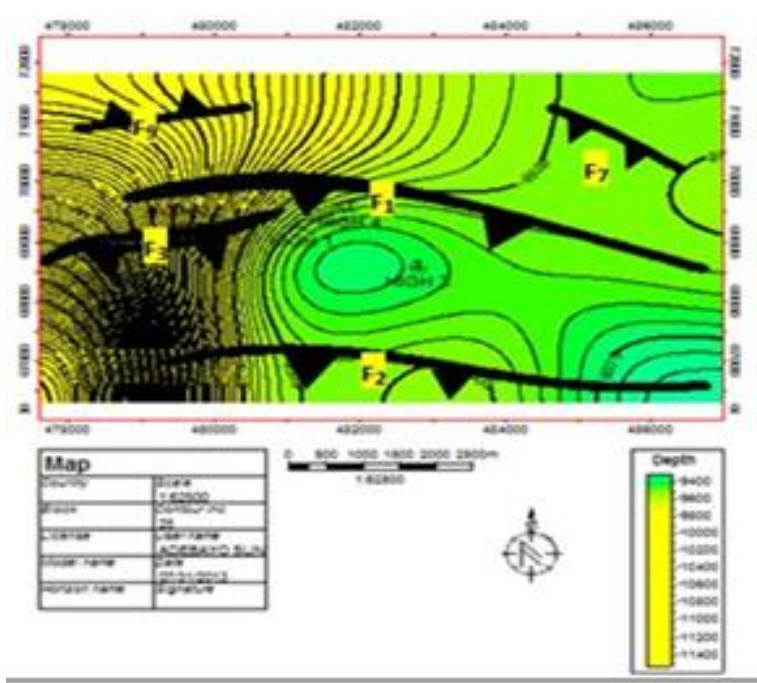

Fig 13: Depth Map for $\mathrm{H}_{6}$ (Contour Interval $25 \mathrm{ft}$ ).

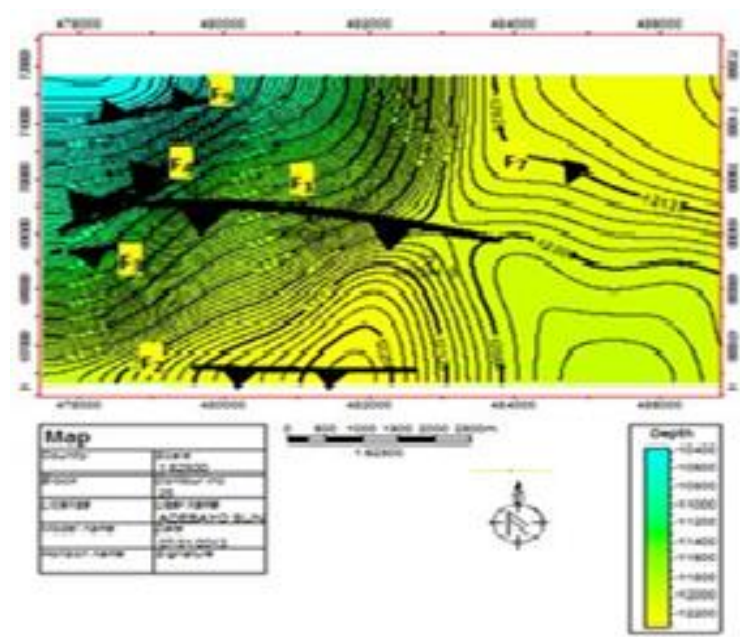

Fig 14: Depth Map for $\mathrm{H}_{7}$ (Contour Interval $25 \mathrm{ft}$ ).
Depth Structural Maps: Seven (7) corresponding depth structural maps were produced from the time structural maps using the check shot survey in Figure 7 to convert from time to depth using the linear equation $\mathrm{y}=4.07598 \mathrm{x}+686.314$, where $\mathrm{y}$ is the converted depth in feet (ft) and $\mathrm{x}$ is the two-way travel time in milliseconds (ms). The depth structural maps were as shown in Figures 8 to 14 . The $\mathrm{H}_{1}$ depth structural map is shown in Figure 8, it ranges from $4550 \mathrm{ft}(1387 \mathrm{~m})$ to $5100 \mathrm{ft}(1555 \mathrm{~m})$. It is the shallowest of the mapped horizons. $\mathrm{H}_{1}$ depth structural map has the same structures (faults, structural highs and lows) as that of $\mathrm{H}_{1}$ time structural map. Figure 9 shows the depth structural map of $\mathrm{H}_{2}$, it ranges in depth from $7250 \mathrm{ft}(2210 \mathrm{~m})$ to $8100 \mathrm{ft}(2469 \mathrm{~m})$. It has structural highs in the north western, north eastern and central areas of the map while structural lows are found in other areas. The structures found on $\mathrm{H}_{2}$ depth structural map are also consistent with that of $\mathrm{H}_{2}$ time structural map. The depth range for $\mathrm{H}_{3}$ is from $7800 \mathrm{ft}$ $(2377 \mathrm{~m})$ to $8625 \mathrm{ft}(2629 \mathrm{~m})$ as shown in Figure 10. Similar structures were also found as that of the time structural map. Figure 11 shows the depth structural map for $\mathrm{H}_{4}$ having a depth range of $8400 \mathrm{ft}(2560 \mathrm{~m})$ to $9500 \mathrm{ft}(2896 \mathrm{~m})$. The $\mathrm{H}_{5}$ depth structural map is shown in Figure 12, it ranges from $8900 \mathrm{ft}(2713 \mathrm{~m})$ to $9800 \mathrm{ft}(2987 \mathrm{~m}) . \mathrm{H}_{5}$ depth structural map has the same structures (faults, structural highs and lows) as that of $\mathrm{H}_{5}$ time structural map. Figure 13 shows the depth structural map of $\mathrm{H}_{6}$, it ranges in depth from $9400 \mathrm{ft}$ $(2865 \mathrm{~m})$ to $11400 \mathrm{ft}(3475 \mathrm{~m})$. It has structural highs in the central area and south western edge of the map while structural lows are found in other areas. The structures found on $\mathrm{H}_{6}$ depth structural map are also consistent with that of $\mathrm{H}_{6}$ time structural map. The deepest horizon, $\mathrm{H}_{7}$ is shown in Figure 14 with a depth range of $10400 \mathrm{ft}(3170 \mathrm{~m})$ to $12200 \mathrm{ft}(3719 \mathrm{~m})$. It is also consistent in terms of structures with its corresponding time map. In summary, it can be deduced from this study that the wells were located to target the rollover anticline formed on the downthrown side of the fault $F_{1}$ (as observed on the structural maps). The time and depth structural maps show system of differently oriented growth faults $F_{1}$ to $F_{7}$. Faults $F_{1}$ and $F_{2}$ are the major growth faults, dipping towards northeast to southwest and are quite extensive. The fault $F_{1}$ lies centrally within the mapped area and extends up to two-third of the entire length of the mapped area. A rollover anticline is formed as a result of deformation of the sediments deposited on the downthrown block of the fault $F_{1}$. The other major fault $F_{2}$, is also extensive and shows sub-parallel relationship with the fault $F_{1}$. Interestingly, this subparallel relationship is sustained in all the structural maps. The fault $F_{1}$ is observed to be closer to the shoreline and can be interpreted as the active fault, 
while the $\mathrm{F}_{2}$ is inactive fault, but must have been active in the past and located in offshore direction of the $F_{1}$, (Nton and Adesina 2011). Other faults are antithetic faults $F_{4}, F_{5}, F_{6}, F_{8}$ and $F_{9}$, and synthetic faults are $F_{3}$ and $F_{7}$, occurring at different positions of the mapped area.

Faults and Sealing Potential of the Study Area: Growth faults and roll-over anticlines are associated with the study area as deduced from the time and depth structural maps. The trapping potential of the field can be attributed to faults or anticlines, acting either as fault assisted or anticline closures respectively (Orife and Avbovbo, 1982; Sales, 1997). Anticlinal and fault assisted closures are regarded as good hydrocarbon prospect areas in the Niger Delta (Weber and Daukoru, 1975). Trapping of hydrocarbons in an anticline is simply by means of closure which may be dependent or independent on faults. The rollover anticlines are formed on the downthrown block of the fault $F_{1}$, which indicate structural closure in these areas (Figures 8 to 14).
Since the primary seal rocks in the Niger Delta are the inter-bedded shale within the Agbada Formation, the juxtaposition of reservoir sands against shale beds due to faulting creates good seal integrity. The shale provides seals in the form of clay smears along these syn-sedimentary faults and vertical fault seals in a compressive stress setting (Weber and Daukoru, 1975). The sealing capability of the faults is dependent on the amount of throws and shale/clay smeared along the fault planes (Busch, 1975; Weber and Daukoru, 1975). According to Weber and Daukoru (1975), faults can be sealing if either the throws are less than $492 \mathrm{ft}$ $(150 \mathrm{~m})$, or the amount shale/clay smeared along the fault planes is greater than $25 \%$. The average throws of the major faults $F_{1}$ and $F_{2}$ calculated are $239.6 \mathrm{ft}$ $(73.0 \mathrm{~m})$ and $108.8 \mathrm{ft}(33.2 \mathrm{~m})$ respectively (Tables 1$)$. Therefore, based on the amount of throws, faults $F_{1}$ and $F_{2}$ are sealing which is in agreement with the work by Weber and Daukoru (1975), signifying that in the Niger Delta, the soft and over- pressured Akata Shale, in most cases rise up to fill the fault zones, thus enhancing their sealing capabilities.

Table 1: Table Showing the Determination of the throws of the major faults $F_{1}$.

\begin{tabular}{lllllll}
\hline Horizon & \multicolumn{2}{c}{$\begin{array}{c}\text { Major Fault } \mathrm{F}_{1} \\
\text { Upthrow }\end{array}$} & \multicolumn{2}{l}{ Downthrow } & \multicolumn{2}{l}{ Fault Throw } \\
\hline & $\mathrm{Ft}$ & $\mathrm{M}$ & $\mathrm{Ft}$ & $\mathrm{m}$ & $\mathrm{A}$ & $\mathrm{m}$ \\
\hline $\mathrm{H}_{2}$ & 8755.57 & 2668.70 & 8904.71 & 2714.16 & 149.14 & 45.46 \\
$\mathrm{H}_{3}$ & 9391.14 & 2862.42 & 9489.41 & 2892.37 & 98.27 & 29.95 \\
$\mathrm{H}_{4}$ & 10345.7 & 3153.40 & 10669.57 & 3252.09 & 365.00 & 111.25 \\
$\mathrm{H}_{5}$ & 10644.06 & 3244.31 & 10948.04 & 3336.96 & 303.99 & 92.67 \\
$\mathrm{H}_{6}$ & 11797.15 & 3595.77 & 12005.11 & 3659.16 & 207.96 & 63.39 \\
$\mathrm{H}_{7}$ & 12142.55 & 3701.05 & 12455.50 & 3796.44 & 312.95 & 95.39 \\
Average & & & & & $\mathbf{2 3 9 . 5 5}$ & $\mathbf{7 3 . 0 1}$ \\
\hline
\end{tabular}

Table 2: Table Showing the Determination of the throws of the major faults $F_{2}$

\begin{tabular}{lllllll}
\hline Horizon & \multicolumn{2}{c}{ Upthrow } & \multicolumn{2}{c}{$\begin{array}{c}\text { Major Fault } \mathrm{F}_{2} \\
\text { Downthrow }\end{array}$} & \multicolumn{2}{c}{ Fault Throw } \\
\cline { 2 - 8 } & $\mathrm{Ft}$ & $\mathrm{M}$ & $\mathrm{Ft}$ & $\mathrm{M}$ & A & $\mathrm{M}$ \\
\hline $\mathrm{H}_{2}$ & 9077.78 & 2766.91 & 9100.24 & 2773.75 & 22.46 & 6.85 \\
$\mathrm{H}_{3}$ & 9568.97 & 2916.62 & 9674.18 & 2948.69 & 105.20 & 32.06 \\
$\mathrm{H}_{4}$ & 11096.24 & 3382.13 & 11244.94 & 3427.46 & 148.69 & 45.32 \\
$\mathrm{H}_{5}$ & 11672.51 & 3557.78 & 11744.16 & 3579.62 & 71.66 & 21.84 \\
$\mathrm{H}_{6}$ & 13006.49 & 3964.38 & 13164.36 & 4012.50 & 157.86 & 48.16 \\
$\mathrm{H}_{7}$ & 13473.56 & 4106.74 & 13620.30 & 4151.47 & 146.74 & 44.73 \\
Average & & & & & $\mathbf{1 0 8 . 7 7}$ & $\mathbf{3 3 . 1 5}$ \\
\hline
\end{tabular}

Conclusion: The 3-D Structural interpretation of "HIGH field"' reveals seven (7) delineated horizons which correspond to the top of sand bodies within the Agbada Formation where most of the hydrocarbon is trapped in the Niger Delta. The time and depth structural maps show subsurface structural geometry and possible hydrocarbon migration and trapping potential by growth fault -related structural traps. Two major growth faults $F_{1}$ and $F_{2}$, were observed to extend throughout the entire mapped area. $F_{1}$ is the active growth fault located near the shoreline, while $F_{2}$ is an older inactive fault located offshore which must have been active in the past. The rollover anticline exists at the down-thrown block of the fault $F_{1}$, which is suggestive of probable hydrocarbon accumulation potential of the sand bodies. Since the primary seal rocks in the Niger Delta are the inter-bedded shale within the Agbada Formation, the juxtaposition of reservoir sands against shale beds due to faulting creates good seal integrity in the study area.

\section{REFERENCES}

Ako, BD; Ojo, SB; Okereke, CS; Fieberg, FC; Ajayi, TR; Adepelumi, AA.; Afolayan, J.F; Afolabi, O; 
Ogunnusi, HO; (2004): Some observations from gravity/ magnetic data interpretation of the Niger Delta, Nigerian. Assoc. Petrol. Explore. Bull. 17:1121

Adeoye, TO and Enikanselu, PA; (2009): Hydrocarbon Reservoir Mapping and Volumetric Analysis Using Seismic and Borehole Data over "Extreme" Field, Southwestern Niger Delta. Ozean J. Appl. Sci. 2(4): 429-441.

Amigun, JO; (2007): Structural interpretation of seismic reflection data: A case study of an ' $\mathrm{X}$ ' field, western Niger Delta. Global J. Pure. Appl. Sci. 13 (1):8-10.

Burke, K; (1972): Longshore drift, submarine canyons and submarine fans in development of Niger Delta. Am. Assoc. Petrol. Bull. 56:1975-1983.

Busch, DA; (1975): Influence of growth faulting on sedimentation and prospect evaluation. Am. Assoc. Petrol. Geol. Bull. 59 (3): 414-419.

Coffen, JA; (1984): Interpreting seismic data: Penwell Publishing Company, Tulsa Oklahoma. pp. 39-118.

Doust, H and Omatsola, E; (1989). Niger Delta, in, Edwards, J. D., and Santogrossi, P.A., eds., Divergent/passive Margin Basins, American Association of Petroleum Geologists_ Memoir 48: Tulsa. Am. Assoc. Petrol. Geol. 48:239-248.

Evamy, BD; Haremboure, J; Kamerling, P; Knaap, WA; Molloy, FA; and Rowlands, PH; (1978): Hydrocarbon habitat of Tertiary Niger Delta: Am. Assoc. Petrol. Bull. 62:277-298.

Galloway, WE; Hobday, DK and Magara, K; (1982): Frio Formation of Texas Gulf Coastal plain depositional systems, structural framework and hydrocarbon distribution. Am. Assoc. Petrol. Geol. Bull. 66: 649-688.

Hooper, RJ; Fitzsimmons, RJ; Grant, N and. Vendeville BC; (2002): The role of deformation in controlling depositional patterns in the South-Central Niger Delta, West Africa: J. Structural Geol. 24: 847-859.

Hosper,, J; (1971). The geology of the Niger Delta area, in the Geology of the East Atlantic continental margin, Great Britain, Institute of Geological Science Report, 70(16): 121-141

Jon, G. and Richard, S; (2004): Petroleum Geoscience: Blackwell Publishing, USA. 54 - 112.

Klett, TR; Ahlbrandt, TS; Schmoker, JW and Dolton, JL. (1997): Ranking of the world's oil and gas provinces by known petroleum volumes: U.S. Geological Survey, Open-file Report, 97-463, CD-ROM.
Merki, P; (1972): Structural Geology of the Cenozoic Niger Delta. In: T.F.J. Dessauragie and A.J. Whiteman (Eds): African Geology. Ibadan University Press, p 635-646.

Microsoft Encarta (2006): Reference Library Premium, DVD-ROM.

Nton, ME and Adesina, AD; (2011): Aspects of structures and depositional environment of sand bodies within tomboy field, offshore western Niger Delta, Nigeria. RMZ - Mat. Geo-Environ. 56(3): 284-303.

Orife, JM and Avbovbo, AA; (1982): Stratigraphic and unconformity traps in the Niger Delta: Am. Assoc. Petrol. Geol. Bull. 65: 251-265.

Owoyemi, AD; (2004): The sequence Stratigraphy of Niger Delta, Delta field, offshore Nigeria. Unpublishised M. Sc. Thesis, Texas A\&M University, $88 \mathrm{p}$.

Petrel $^{\mathrm{TM}}$ Workflow Tools, (2010): Petrel Help Manual. Schlumberger Information Solution. pp 13.

Rotimi, OJ; (2010): Sequence stratigraphy study within a chronostratigraphic framework of 'Ningning field', Niger Delta. RMZ - Mat. Geo-Environ. 57 (4): 475500 .

Sales, Jk.; (1997): Seals strength versus trap closures-a fundamental control on the distribution of oil and gas. In: R. C. Surdam, (ed.), Seals trap and petroleum system. Am. Assoc. Petrol. Geol. 67:57-83

Stacher, P; Ozumba, BM and Ehoche, P; (1993): Revised Chronostratigraphic and Sequence Stratigraphic Chart, Niger Delta, Nigeria, S.P.D.C. Exploration Report no 93-01.

Vikesh (2013): Use of variance attribute. Retrieved 11, June 2013. www.epgeology.com/home/Geology Disciplines/Geophysics (services)

Weber, KJ and Daukoru, EM; (1975). Petroleum geology of the Niger Delta: Proceedings of the Ninth World Petroleum Congress, volume 2, Geology: London, Applied Science Publishers, Ltd., p. 210-221.

Whiteman, AJ; (1982). Nigeria: It's Petroleum Geology: Resources and Potential.1 and 2. Graham and Trottan: London, UK. 394 